\title{
ANALYSIS OF HOME OWNERSHIP FINANCING FOR ISLAMIC BANKS IN INDONESIA THROUGH SHARIA ASSET BACKED SECURITIES- PARTICIPATION LETTER
}

\author{
${ }^{1}$ Suci Aprilliani Utami, ${ }^{2}$ Aneu Cakhyaneu, ${ }^{3}$ Neni Sri Wulandari \\ 1,2,3Program Studi Ilmu Ekonomi dan Keuangan Islam, Universitas Pendidikan Indonesia \\ Jl. Dr. Setiabudi No.229, Isola, Kec. Sukasari, Kota Bandung, Jawa Barat 40154 \\ ${ }^{1}$ suci.avril@upi.edu, ${ }^{2}$ aneufpeb@upi.edu, ${ }^{3}$ neni.wulandari@upi.edu
}

\begin{abstract}
This research was conducted to find out the financing opportunities of home ownership financing for Islamic banks through Sharia Asset Backed Securities-Participation Letters (EBAS-SP) in Indonesia. This study uses the Analytic Hierarchy Process (AHP) approach, following the priority of the strategy as a solution that can be offered. The results of this study indicate that: First, there are 4 issues of issues in developing the ability to mitigate the risk of home ownership financing for Islamic banks in Indonesia through the asset-backed effect of Islamic assets-participation letters, including legal / structural issues, sharia issues, operational issues and human resource issues. Second; For priority issues in terms of the use of Sharia Asset Backed Securities instruments and Participation Letters are operational aspects and aspects of human resources (HR). Third; the results of this study also show a picture of a solution in the strategy of increasing risk mitigation in PPR products through EBAS-SP for all four issues. And finally, the priority solution in solving problems based on expert agreement is the solution in legal / structural aspects, sharia aspects and operational aspects.
\end{abstract}

Keywords: EBAS-SP, home ownership financing, Islamic Banks, AHP

\section{INTRODUCTION}

\section{A. Background}

ASEAN Economic Community (AEC) for the new banking sector will take effect starting in 2020. The banking industry, especially Islamic banking which is growing and is still relatively small must make careful preparations in various aspects because banks in the region will be more expansive to expand into market shares that have so far been unreachable and worked on by the Islamic banking. (Divisi Pengembangan Produk dan Edukasi, 2016).

The challenges facing Islamic financial institutions facing the AEC are the innovation of developing products and services that are competitive and based on community needs. Islamic financial institutions must create unique products and services that can meet the real needs of the community. This is because most Muslim communities in Indonesia prioritize aspects of service and convenience compared to the islamic aspects. (Hidayat, 2018).

The facts show that the development of the product as one of the core facilities to meet the needs of the community for Islamic banking transactions and to improve services to the public, has not been running optimally. For example, the House Ownership Product (PPR) as a competitive 
product of Islamic banking has not experienced growth as other products. This happens because of the lack of product development that is more flexible in time. Islamic banking itself has more of its products based on fixed income financing that has similarities to conventional patterns that use fixed income structures (fixed income) and tend to be short and medium term (Divisi Pengembangan Produk dan Edukasi, 2016).

In fact, housing is one of the main needs of the community, where rapid population growth causes the need for housing to increase (Kementrian Pekerjaan Umum dan Perumahan Rakyat Repubik Indonesia, 2019). However, it turns out, the need for housing is often hampered by the unavailability of funds owned by the community, so that many people use banking services as an alternative to home ownership financing.

In the distribution process, Islamic banks must be good at assessing the appropriateness of the debtor who submitted it. This is important so that Islamic banks can avoid losses due to problem financing. The quality of financing is important so good mechanisms must be used to reduce the problems of moral hazard and adverse selection (Fianto, Maulida, \& Laila, 2019), (Morduch, 1999).

The occurrence of this problematic financing will lead to disparities in Islamic banking assets and liabilities in housing finance. This gap is one of the main problems in banking. Asset and liability management plays a very important role in banking activities (Novickytė \& Petraitytè, 2014), (Claessens \& Horen, 2012) (John \& Pedro, 2013). Due to the fact, on the one hand home ownership loan financing has a long-term tenor ranging from 10 to 15 years, but on the other hand the deposit funds used for this financing have a short-term tenor (Mingka, 2016).

Thus, various efforts and appropriate policies are needed to develop Home Ownership Financing products in Islamic banking in Indonesia. If the Home Ownership Financing product develops, it is expected to increase the market share of the Islamic banking industry.

One way to anticipate the gap between assets and liabilities is through Islamic capital market instruments, namely the asset-backed effect. To anticipate this, Islamic banks must apply the precautionary principle in providing loans or financing for home ownership. The technique used to reduce the risk of financing by Islamic Banks is not much different from that applied by Conventional Banks (Winarto, 2017).

But the difference can come from the practice of using EBAS-SP. The Financial Services Authority as a financial regulator in Indonesia issues POJK Number 20 / POJK.04 / 2015 regarding the issuance and Sharia EBA Requirements as of November 10,2015 . It is stated that the issuance of KIK-EBA products is an effort to overcome the gap in housing needs for the community through securitization. This happens because housing finance no longer relies on Islamic banking deposit funds intended to fund short-term financing. The Sharia EBA is here to make home ownership prices more affordable with long-term financing, because Sharia banking can obtain liquidity through the capital market by asset securitization.

Mitigation of the risk of housing finance through EBAS-SP, according to sharia 
economic practitioner Agustianto Mingka, is a breakthrough to address the gap in housing needs for the community. With tawriq (securitization), housing finance is no longer limited to relying on bank deposit funds which are intended for short-term funding. EBA Syariah has become a positive breakthrough that requires the support of all parties, as housing prices become more affordable with long-term financing (Mingka, 2016).

\section{B. Research Question}

From the explanation above, it can be drawn a red line that there are several issues related to Home Ownership Financing products in Islamic banking in Indonesia, including related to sharia issues, legal issues, and operational issues. Due to limited costs, time and abilities and interests, the research related to Islamic home ownership financing through EBAS-SP needs to be limited. The focus of this study is on the problem of asset and liability gaps in Islamic banking in financing of home ownership products in Indonesia. So the formulation of the problem is:

\section{Research Objective}

Based on the problems that have been described above, in general the purpose of this study is to analyze the biggest problems of financing home ownership through the EBAS-SP instrument and solutions to resolve these problems by using several aspects that affect based on research results.

\section{Research Methods}

\section{Data Collection Method}

The instrument used in this study was primary data through a questionnaire that was developed using a ratio scale. The scale used has a range from 1-9 as follows:
Table 1. Comparison of Verbal Scale with Numeric Scale

\begin{tabular}{|l|c|}
\hline \multicolumn{1}{|c|}{ Verbal Rating Scale } & $\begin{array}{c}\text { Numeric } \\
\text { Scale }\end{array}$ \\
\hline Very much greater importance & 9 \\
\hline Among the grades 7-9 & 8 \\
\hline Very greater level of importance & 7 \\
\hline Among the grades 5-7 & 6 \\
\hline Greater importance & 5 \\
\hline Between 3-5 & 4 \\
\hline Slightly greater level of importance & 3 \\
\hline Between 1-3 & 2 \\
\hline Same level of importance & 1 \\
\hline
\end{tabular}

Priorities on the scale of ratios are fundamental numbers that make it possible to carry out basic arithmetic operations (Ascarya, 2005). The scale was obtained from Pairwise Comparison which is believed to be the most accurate in measuring the factors that make up the hierarchy (Rusydiana \& Devi, 2013).

Meanwhile, respondents were chosen deliberately (purposive sample) by considering respondents' understanding of the problem of mitigating the risk of home ownership financing for Islamic Banks in Indonesia. The number of respondents in this study consisted of nine people, with the consideration that they were competent enough to represent the entire population. Data collection techniques used in this study are:

1) Direct Observation

2) Interview with the questionnaire. The questionnaire was filled out by the respondents accompanied by researchers to maintain the consistency of the answers given (Rusdyana, 2015).

3) Literature study, which is a technique to collect data from various relevant relevant sources such as books, journals, websites, articles, and other literature related to the research being studied. 


\section{Data Collection Method}

The data analysis method used in this study is the Analytic Hierarchy Process (AHP), which is a flexible model to provide opportunities for individuals or groups to develop ideas that define problems by making their respective assumptions and obtaining desired solutions from it (Saaty, 1993).

There are three basic principles of AHP:

1) Describe and describe hierarchically or break down the problem into separate elements

2) Differentiation between priorities and synthetics or ranking elements according to their relative importance

3) Logical consistency or guarantee that all elements grouped logically are warned consistently according to a logical criterion.

\section{DISCUSSION}

\section{A. Theoritical Basis}

\section{Home Ownership Financing}

Financing is Funding provided from the first party to another party to support the planned investment, both by itself and by the institution (Ilyas, R., 2015). In other words, financing is funding spent to support a planned investment (Muhamad, 2016). This financing is one of the main tasks of the bank (Antonio, 2001). The bank provides various types of financing to a variety of customers for various purposes (Joshua Yindenaba Abor et.al, 2014), (Bedendo \& Linus, 2018).

Islamic banks run their activities based on sharia principles which are key in practice (Fekri Ali Sawtari, et.al, 2015), (Mehmet, Gamze, Ender, \& Amine, 2020). The bank provides home ownership financing services to customers who want a special loan to meet the needs of building or renovating a house. This type of service arises because there are conditions where the fulfillment of housing needs is getting higher and higher but is not matched by the people's purchasing power in cash.

Home ownership financing (PPR) is a form of financing product run by Islamic financial institutions to be able to meet the needs of the community in terms of purchases or home improvement efforts using contracts based on Islamic law (Novan, 2014). This Islamic Sharia refers to asset-based practices, prohibits interest (usury), and promotes the sharing of risk between the Bank and the Customer (Mahfudz, 2016).

In Indonesia there are currently 2 types of PPRs, namely Subsidized PPRs intended for people who have a lower middle income and non-subsidized PPRs intended for the whole community based on the PPR provisions stipulated by Islamic Banks.

Home ownership financing generally uses a Murabahah (sale-purchase) contract, that is, a contract of sale of goods, in this case the house, where the seller states the acquisition price and the desired margin at the time of sale to the buyer by mutual agreement. The other contract is home ownership financing with the Ijarah Muntahiyah Bittamlik (IMBT) agreement, which in fact is still rarely used, is financing using a leasepurchase agreement where the customer rents goods or in this case the house at the end of the lease period will transfer the ownership of the house. The transfer of ownership of a house with this contract can be carried out in several ways, namely through a grant or sale (Satria \& Setiani, 2018). 


\section{Sharia Asset Backed Securities - Participation Letters (EBAS-SP)}

In the financial literature, securitization is generally defined as a creative way to raise funds through the issuance of securities that are supported by future cash flows from income-producing assets (Gorton, 2012), (Tobias, 2018). By trading procedures, securitization is the transformation of illiquid assets such as mortgages and can be traded on the capitalist market (Kruger, 2018). With trading procedures, asset securitization is different from traditional debt-based debt or loan based assets because loans or other financial claims are given or sold to third parties (Giddy, 2000).

Asset securitization is driven by market trends in allocating assets to investors who are most knowledgeable about the value of assets (Tsung-Kang, Hsien-Hsing, \& JingSyuan, 2019). Asset securitization swaps future cash inflows with cash flows at the same time, which enhances the monitoring and control of management expenses (Edward M. Iacobucci, 2005), (Arif, 2020). Asset securitization also influences bank behavior and its implications for financial stability (Deku, 2019), (Thomas, 1999),

According to Elena Loutskina, securitization allows banks to convert illiquid loans into liquid funds, securitization reduces bank ownership of liquid securities and increases their lending capabilities (Loutskina, 2011). Securitization has a positive impact on financing / credit risk at banks (Andre Uhde, 2010), (Kristina Lützenkirchen, 2014). In addition, investment bank securitization activities reduce lenders' incentives to screen borrowers carefully (Taylor D. Nadauld, 2013), (Binghui, 2018).
This securitization of assets is found in the capital market. In Indonesia, the capital market is growing rapidly along with the development of technology that has a positive impact on economic development that is getting better. Capital markets that are based on Sharia principles are also present as a counterweight to the problems that occur in conventional capital markets. The Islamic capital market as part of the Islamic economic system, functions to improve efficiency in the management of resources and capital and support investment activities (Imam Wahyudi, 2014). Sharia capital market products come in the form of sharia shares, sharia mutual funds, sukuk and sharia asset-backed securities.

Asset Backed Securities, called "EBA", are securities portfolios consisting of financial assets in the form of bills arising from commercial paper, credit card bills, future receivables, collection of loans, loans including loans to house ownership or apartment, debt securities guaranteed by the Government, credit enhancement / cash flow facilities, as well as equivalent financial assets and other financial assets related to these financial assets (KSEI, 2015).

The Financial Services Authority as a financial regulator has issued POJK Number 20 / POJK.04 / 2015 concerning Issuance and Sharia EBA Requirements as of November 10, 2015. There are two forms of Sharia EBA that are regulated. First, the Asset Backed Securities Collective Investment Contract (KIK), which is a contract between the Investment Manager and the Custodian Bank that binds holders of Sharia Asset Backed Securities in which the Investment Manager is authorized to manage the collective investment portfolio 
and the Custodian Bank is authorized to carry out Collective Custody, the implementation of which is Collective Custody, the implementation of which is does not conflict with Sharia Principles on the Market.

Second, Sharia EBA, namely Asset Backed Securities - Participation Letters issued by the Issuer with a portfolio in the form of a collection of receivables and proof of ownership proportionally to a collection of receivables that are jointly owned by a group of EBA-SP holders. The Financial Assets must be obtained by the Issuer from the Originator through the sale of off / loose sale and sold by the Issuer to EBA-SP holders through the sale / purchase break off legally and is supported by the opinion of the Financial Services Authority No. 23 / POJK.04 / 2014.

Islamic asset-backed securities according to Riswinandi as the Chief Executive of IKNB Supervisors, have carefully selected underlying assets such as portfolios (Housing Financing). There are at least 32 criteria in ranking EBAS-SP, starting from the analysis of the PPR profile, service provider evaluation, transaction structure analysis and cash flow analysis. In addition to meeting the funding requirements needed for housing, the existence of this instrument can also strengthen the structure of the financial market in Indonesia.

\section{B. Research Result}

\section{Description of Home Ownership Financing Problem through EBAS-SP Instrument in Indonesia}

The global financial crisis highlights the potential for conflict between increasing access to housing finance and maintaining financial stability (Eugenio Cerutti, 2017). Home ownership financing facilities in banks are still the main source of financing for customers.

As many as $73.4 \%$ of respondents used housing finance through banks, while $19.05 \%$ bought cash in stages and 6.64\% bought in cash. Bank Indonesia survey results reveal that the number of home sales in the second quarter of 2019 contracted to $15.79 \%$ YoY. However, the majority of respondents stated that there were major factors that hindered the growth of residential property sales in the second quarter of 2019, namely weakening purchasing power, licensing issues and bureaucracy (Adharsyah T, 2019).

Islamic banks in dealing with this have risk management both in the short and long term, especially to measure liquidity risk (AbdulRahman, Ahmad, \& Mohd Said, 2018), (Gixia \& Ho-Mou, 2014). Based on literature sources as well as interviews with several experts and practitioners, several problems were obtained in developing the ability to mitigate the risk of housing finance for Islamic banks in Indonesia through the effects of sharia asset-backed securities, including:

1) Legal and Structural Issues

- Credit Enhanchment Option (allegedly changing the character of the transaction)

- The form of ownership (conveyance) of securities

- Some clauses refer to conventional banks and EBA-SP

2) Sharia Issues

- There are differences of opinion between scholars regarding BayAl-Dayn (sale and purchase of accounts payable), where the underlying assets are receivables

- The securitized underlying assets 
are made into two separate instruments

3) Operational Issues

- The difference between the banking contract system and the fatwa on the use of EBAS-SP

- There is no draft regulation that provides for opening access to Islamic banking to be involved in this funding system

4) Human Resources Issues

- Weak understanding of HR on EBAS-SP products

- Not Professional yet

- Managerial technique is not good

2. Priority Issues of Home Ownership Financing Products for Islamic Banking through the EBAS-SP Instrument in Indonesia

\section{1) Legal and Structural Issues}

Legal or structural aspects discuss issues concerning in terms of regulations in the development and supervision of IB PPR products using EBAS-SP, these issues include:

- Credit Enhanchment Option (allegedly changing the character of the transaction. Credit enhanchment is a facility provided to Issuers to improve the quality of financial assets transferred in the context of payment to Investors. This facility is provided by the Bank as the original creditor after the asset securitization transaction has taken place.

- The form of ownership (conveyance) of securities.

- Some clauses refer to conventional banks and EBA-SP.

- DSN rules and edicts are not yet fully compliant with sharia. 


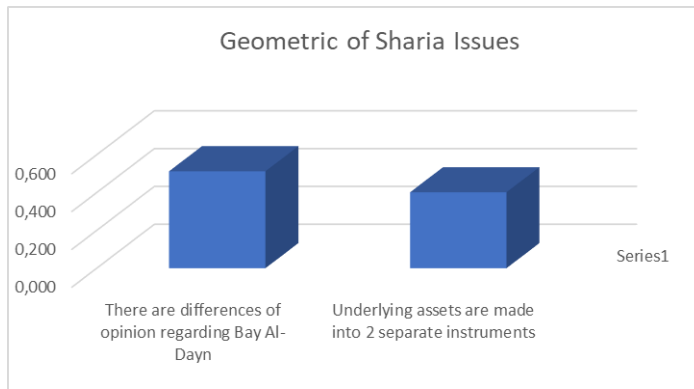

Picture 2.

Geometric Mean of Sharia Aspects

Based on the geometric mean (Gmk) obtained from 9 subjects interviewed, the two problems of sharia aspects show that the indicators that indicate there are differences of opinion regarding Bay Al-dayn get the highest value of 0.513 .

\section{3) Operational Issues}

Operational issues discuss issues concerning the operational aspects of the transaction carried out. These operational issues include:

- The difference between the banking contract system and the fatwa on the use of EBAS-SP for housing finance where the majority of Islamic banks use the Murabahah contract while the EBAS-SP uses the Musyarakah Mutanaqishah and Ijarah Muntahiyya Bittamlik contracts.

- There is no draft regulation that provides for opening access to Islamic banking to be involved in this funding system.

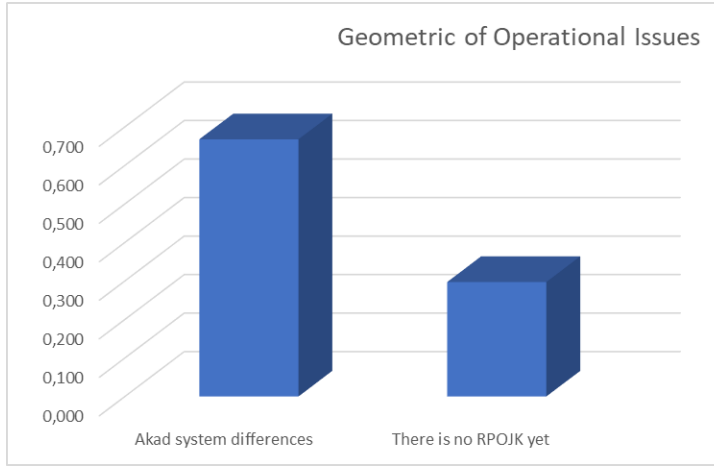

Picture 3.

Geometric Mean of Operational Aspects
Based on the geometric mean (Gmk) obtained from 9 subjects interviewed, of the three legal aspects problems indicate that the indicator of differences in the contract system gets the highest value of 0.668 and the next problem is an indicator of the absence of RPOJK.

\section{4) Human Resources Issues}

HR issues discuss issues in terms of human resources. Human resources involve "knowledge, skills, networks, and energy and, what sustains them, their physical and emotional health, intellectual abilities, personality and motivation (Boxall, 2013)

These Human Resources Issues include:

- Weak understanding of HR for EBAS-SP products.

- Not Professional.

- Managerial technique is not good.

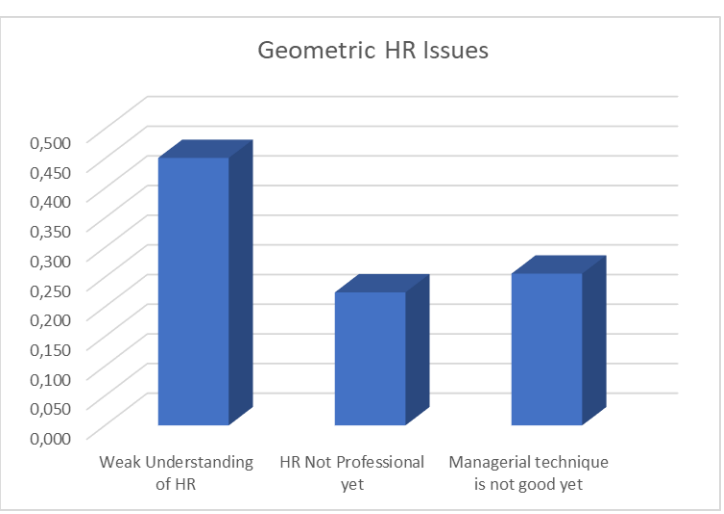

Picture 4.

Geometric Mean of Human Resources Issues Based on the geometric mean (Gmk) obtained from 9 subjects interviewed. Of the three legal aspects, the indicator shows that the weak indicator of human resources understanding gets the highest value, 0.451 . The next problem is the indicator of managerial technique is not good, namely 0.256 and the last is unprofessional human resources is 0.224 . 


\section{5) Overall Problem}

The main focus of the provision of housing finance by banks through capital market instruments is to increase access of lowincome people to have decent housing. In this case, large funds are needed to meet the target and the largest housing finance portfolio comes from the banking industry, including Islamic banking.

Home ownership financing facilities in banks are still the main source of financing for customers, but there are problems with the gap between assets and liabilities that come from housing finance for banks. Therefore, various appropriate efforts and policies are needed to develop Home Ownership Financing products in Islamic banking in Indonesia.

The Financial Services Authority recommends that Islamic banks use Sharia Asset Backed Securities instruments in the form of Participation Letters to narrow the gap. However, various problems arose related to the development of this instrument. For more clearly the Gmk results of each indicator can be seen in Figure 5 below:

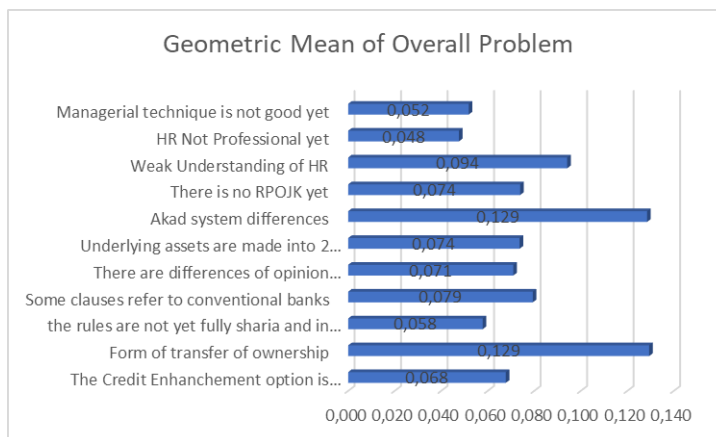

Picture 5.

Geometric Mean of Overall Problem

The agreement of the experts in this study was calculated through the Rater agreement with Kendall's Coefficient of Concordance or the value of $\mathrm{W}$ as a measure. Following is the agreement of the experts in terms of aspects of the problem:

Table 2.

Kendall's Coefficient of Concordance Problem Aspects

\begin{tabular}{|c|l|c|l|}
\hline No & \multicolumn{1}{|c|}{ Aspects } & W & Information \\
\hline 1 & Legal/Structural & 0,441 & $\begin{array}{l}\text { Moderate } \\
\text { Agreement }\end{array}$ \\
\hline 2 & Shariah & 0,198 & $\begin{array}{l}\text { Weak } \\
\text { Agreement }\end{array}$ \\
\hline 3 & Operational & 2,086 & $\begin{array}{l}\text { Strong } \\
\text { Agreement }\end{array}$ \\
\hline 4 & $\begin{array}{l}\text { Human } \\
\text { Resources }\end{array}$ & 0,778 & $\begin{array}{l}\text { Strong } \\
\text { Agreement }\end{array}$ \\
\hline 5 & Overall & 0,055 & $\begin{array}{l}\text { There is no } \\
\text { Agreement }\end{array}$ \\
\hline 6 & General & 0,21 & $\begin{array}{l}\text { Weak } \\
\text { Agreement }\end{array}$ \\
\hline
\end{tabular}

From this table it can be seen that the operational aspect has a strong level of agreement, it can also mean that the expert evaluates this aspect with a value that is not much different. Expert agreement on operations is also evidenced by differences in the structure and contract system which are the most problematic aspects. Furthermore, for HR aspects, experts have a strong level of agreement, this is evidenced by the weak understanding of human resources being the most problematic aspects of human resource issues. For legal / structural aspects, the expert has a medium agreement. As for the sharia aspect, expert answers tend to be varied. Experts have different views on these two aspects, so the agreement of experts tends to be weak. Overall, the aspects of the problem expert did not have agreement on the assessment given. And finally for the general aspects of the issue of agreement experts are considered weak.

It can be concluded that the problem that becomes the priority of experts in financing through the EBAS-SP instrument is the problem in its operations which is illustrated 
by the difference in contract structure and contract system used in this instrument. In addition, the lack of understanding of the actors impedes the development of housing finance products through this EBAS-SP instrument. Meanwhile, legal and structural issues become priority issues afterwards.

\section{Description of Solution for Issues of Home Ownership Financing Products for Islamic Banking through the EBAS-SP Instrument in Indonesia}

Various problems that exist in the process of liquidating assets that are not liquid by selling a group of assets from (the originator) to another party (investors) through the issuance of securities in order to make alternative financing for housing ownership certainly requires an appropriate and smart solution but do not conflict with the fulfillment of the principle sharia. The fulfillment is mainly related to the underlying assets and the structure of the securitization transaction itself.

The first problems that arise include legal / structural problems which include the choice of credit management that is allegedly able to change the character of the transaction. Credit enhancements are rights or other assets that are designed to ensure the distribution of proceedings to EBA holders is carried out in accordance with the agreed time. This is used to improve the rating of Securities to be issued in the securitization. Generally there are 2 forms of credit enhancement, namely: internal credit enhancement (excess spread, overcollateralization, reserve account and Securities issuers acting as subordinate investors); and external credit enhancements (surety bonds, wrapped securities, letters of credit, and cash collateral accounts) (Tim
Kajian Pengembangan Syariah di Pasar Modal, 2010).

This credit enhancement process requires a more detailed assessment because shariah compliance is not regulated in detail. Credit enhancement is an option and changes some of the character of the transaction. Therefore, insofar as credit enhancement is an option (not a necessity), it is better before using it first to be studied by policy makers together with experts and academics in the field of sharia economics for shariah compatibility.

Furthermore, the form of transfer (ownership) of Securities from the Securities, it is required that the adequacy of the ownership element must be given to investors. To do this, investments made by investors must be directly related to the business risk of the securitized assets. In addition, sharia provisions that must be met in relation to this matter are in the securitization, securitized assets may not be guaranteed or become the underlying instruments.

In conventional securitization, the practice that is often done is that one asset that is securitized is made two separate instruments. One instrument is the main instrument and the other is the instrument of interest. In addition, there are other criteria that must be met, namely:

1) cash flows from securitized assets must be specifically dedicated to linking ownership interests with identifiable economic activities; and

2) payment obligations to investors are unconditional and unsecured and are not guaranteed obligations (guaranteed promissory notes) (Tim Kajian Pengembangan Syariah di Pasar Modal, 2010). 
The next problem is related to the contract structure in the securitization process. Because securitization in general is a transfer of accounts that are still receivable (bay al dayn) there are differences of opinion among scholars. In Indonesia, sharia trading of receivables is not permitted because there is an element of risk that debtors cannot pay (gharar). Therefore, it is necessary to further study the scheme in the formation and issuance of securities.

4. Priority of Solution for Issues of Home Ownership Financing Products for Islamic Banking through the EBAS-SP Instrument in Indonesia

\section{1) Solution to Legal/Structural Problems}

Priority solutions in legal / structural issues include the following:

- Reviewing credit enhancement options

- The form of transfer (ownership) of securities must be directly related to the business risk of the assets being secured

- Completing DSN and PBI fatwas

- Carry out joint research with experts and academics

Of the four solutions chosen, the solution prioritized by the experts was the solution to complete the DSN fatwa and Bank Indonesia Regulation which had a Gmk value of 0.336 . The next solution is the form of diversion (convayance) which has a Gmk value of 0.249 . The next priority solution is to review the credit enhanchment options with Gmk 0.148. Whereas the final solution is to conduct joint research with experts and academics.

To find out the value in a nutshell, see Figure 6 below:

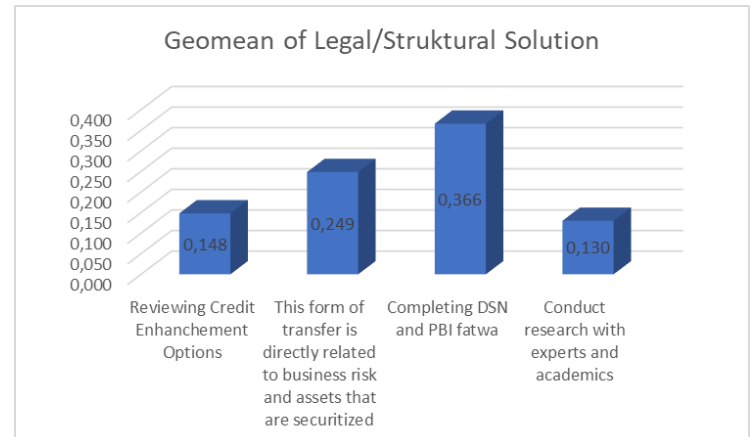

Picture 6. Geometric Mean of Solution to Legal/Structural Issues

\section{2) Solution to Sharia Issues}

Priority solutions in sharia issues include the following:

- Study and improve the structure of the contract in the transfer of asset securitization

- Underlying assets which are securitized are made into two separate instruments

Of the two solutions chosen, the solution prioritized by experts is a solution where the securitized underlying assets are made into two separate instruments so that in accordance with the Shariah compliancity, this aspect of the solution has a value of Gmk 0.512. The next solution is to study and improve the structure of the contract in the transfer of securitization assets that have a Gmk value of 0.392 .

To find out the value in a nutshell can be seen in Figure 7 below:

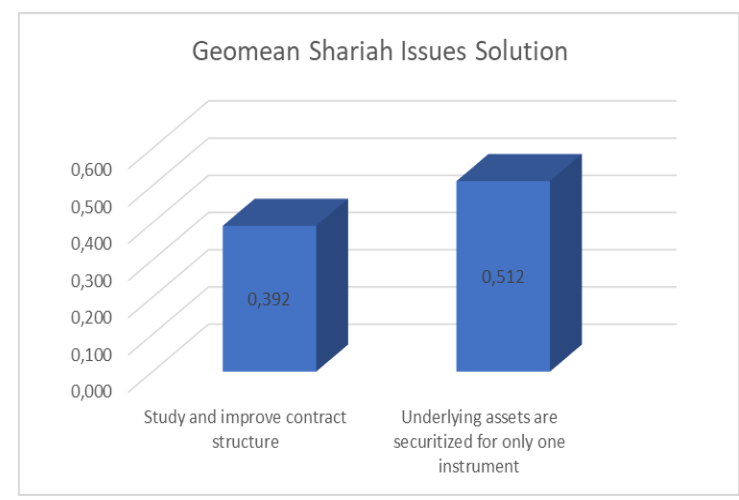




\section{Picture 7. Geometric Mean of Solution to Shariah Issues}

\section{3) Solution to Operational Issues}

Priority solutions in operational issues include the following:

- Adjust the banking contract with the fatwa on the use of EBAS-SP

- $\quad$ Make RPOJK

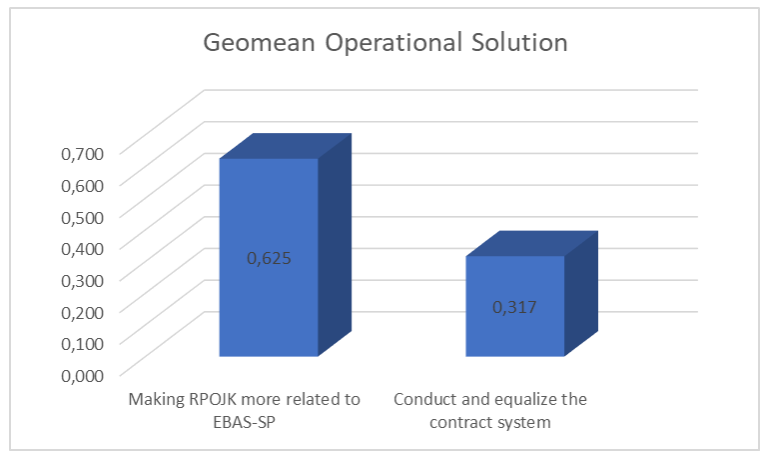

Picture 8. Geometric Mean of Solution to Operational Issues

Of the two solutions chosen, the solution prioritized by experts was a solution to make RPOJK more related to EBAS-SP, an aspect of this solution that has a Gmk value of 0.625 . The next solution is to study and improve the contract system in transferring securitization assets that have a Gmk value of 0.317 .

\section{4) Solution to HR Issues}

Priority solutions in human resource problems include the following:

- Weak understanding of HR for EBASSP products

- Not Professional yet

- Managerial Technique is not good yet
Geomean Solution to SDM Issues

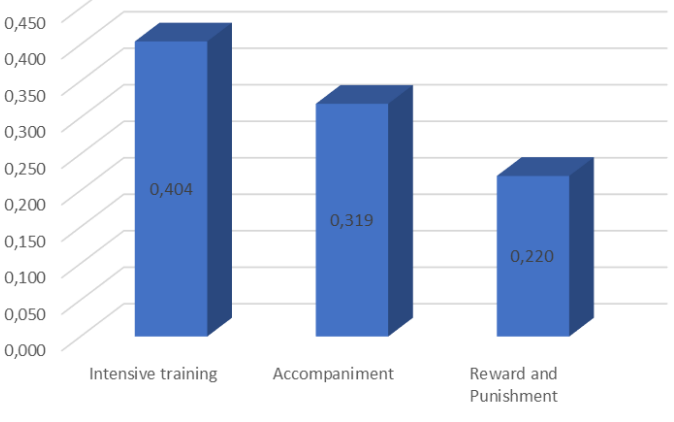

Picture 9. Geometric Mean of Solution to HR Issues

Of the three solutions chosen, the solution prioritized by experts is a solution for conducting intensive training related to EBAS-SP, this aspect of the solution which has a value of Gmk of 0.404 . The next solution is to provide assistance to HR which has a Gmk value of 0.319 . And the last solution related to the problem of human resources is to carry out a process of reward and punishment to human resources, where this aspect has a value of Gmk 0.220.

\section{5) Overall Solution}

Overall, the indicator considered the best solution is to conduct intensive training on human resources in the Banking and Islamic Capital Market with Gmk of 0.135. For indicators considered the next best solution is to make RPOJK and PBI related to EBASSP products with Gmk value of 0.120 . For indicators considered the last solution are or indicators that have the smallest Gmk value is an indicator where there is a need for a study related to credit enhanchment with a Gmk value of 0.043 . 


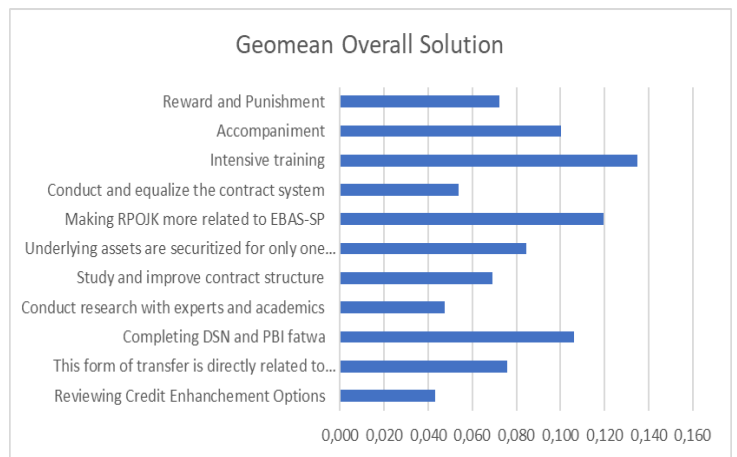

Picture 10. Geometric Mean of Overall Solution to

The agreement of the experts in this study was calculated through the Rater agreement with Kendall's Coefficient of Concordance or the value of $\mathrm{W}$ as a measure. The following will discuss the agreement of the experts in terms of aspects of the solution. The following are the results of the agreement of the experts in the aspect of solutions:

Table 3.

Kendall's Coefficient of Concordance Solution Aspects

\begin{tabular}{|c|l|c|l|}
\hline No & \multicolumn{1}{|c|}{ Aspects } & W & Information \\
\hline 1 & Legal/Structural & 0,726 & $\begin{array}{l}\text { Strong } \\
\text { Agreement }\end{array}$ \\
\hline 2 & Shariah & 1,494 & $\begin{array}{l}\text { Strong } \\
\text { Agreement }\end{array}$ \\
\hline 3 & Operational & 2,086 & $\begin{array}{l}\text { Strong } \\
\text { Agreement }\end{array}$ \\
\hline 4 & $\begin{array}{l}\text { Human } \\
\text { Resources }\end{array}$ & 0,374 & $\begin{array}{l}\text { Moderate } \\
\text { Agreement }\end{array}$ \\
\hline 5 & Overall & 0,71 & $\begin{array}{l}\text { Strong } \\
\text { Agreement }\end{array}$ \\
\hline 6 & General & 0,02 & $\begin{array}{l}\text { There is no } \\
\text { Agreement }\end{array}$ \\
\hline
\end{tabular}

From this table it can be seen that the legal/ structural aspect has the strongest level of agreement, it can also mean that the expert evaluates this aspect with a value that is not much different. Expert agreement on legal / structural aspects where the solution to complete the DSN and PBI fatwa is the main solution with a value of $0.336 \mathrm{Gmk}$.
Furthermore, for the aspects of sharia, the expert has a strong level of agreement. This is evidenced by the two solutions being the solution agreed by the expert to solve the sharia problem with a value of Gmk 0.512 with the underlying assets being isolated for only one instrument and 0.392 by studying and improving the structure of the contract.

For legal / structural aspects, the expert has a strong agreement as well, this is evidenced by the expert agreement in the solution by making RPOJK which is more related to the EBAS-SP instrument with a Gmk value of 0.625 and equating the contract system with a value of Gmk of 0.317 . As for aspects of human resources, the answers of experts tend to be varied, but experts have views that are not much different from the three aspects so that the agreement of experts tends to be moderate.

Overall, the aspects of the expert solution have an agreement on the assessment given. And finally for the general aspects of the issue of agreement experts are considered weak.

So it can be concluded that the priority solutions in the problem of financing housing ownership using EBAS-SP are legal / structural aspects, sharia aspects and legal and structural aspects. The experts have a strong agreement to complete the fatwa of the National Sharia Board and Bank Indonesia Regulations that are in accordance with the existing contract criteria for housing finance with Sharia Asset Backed Securities instruments. 
Suci Apriliani Utami, Aneu Cakhyaneu, Neni Sri Wulandari: Analysis of Home Ownership Financing...

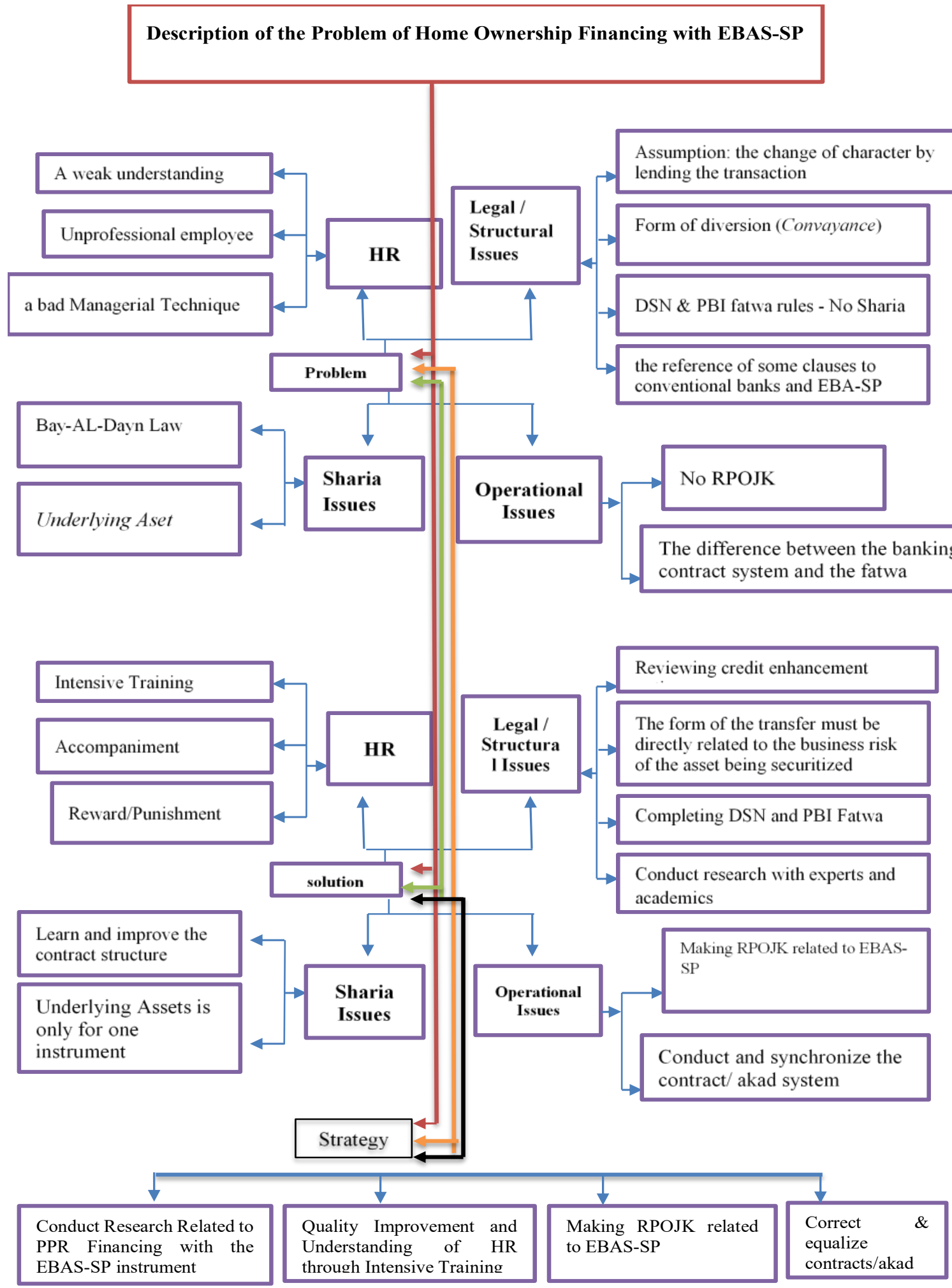

Picture 11.

Description of the Problem, Solution and Strategy of Home Ownership Financing using Sharia Asset Backed Securities - Participation Letter 


\section{CONCLUSION}

The priority issues in home ownership financing products through the EBAS-SP instrument in Indonesian Islamic Banking are operational aspects and human resources aspects. The experts agree that in operational aspects there are differences in the structure and contract system which are the most problematic aspects. In addition, the lack of understanding of the actors impedes the development of housing finance products through this EBAS-SP instrument. Meanwhile, Islamic, legal and structural issues become priority issues afterwards.

Therefore, the experts have a strong agreement in 3 solutions and the agreement is in 1 solution, the expert states that the priority of the solution in the strategy of increasing risk mitigation in PPR iB products through the EBAS-SP instrument can be done through solutions related to legal / structural aspects, aspects of sharia, operational aspects. The Expert has a strong agreement on these three aspects which is the best solution in solving financing problems using the EBAS-SP instrument. In addition, aspects of human resources are also important for problem solving.

\section{BIBLIOGRAPY}

Abdul-Rahman, A., Ahmad, A. S., \& Mohd Said, N. H. (2018). Does financing structure affects bank liquidity risk? Pacific-Basin Finance Journal, 52, 2639. doi:https://doi.org/10.1016/j.pacfin .2017 .04 .004

Adharsyah T. (2019, Agustus 12). cnbcindonesia. Retrieved from https://www.cnbcindonesia.com/news/ 20190812115634-4-91312/duh-sektorproperti-masih-suram-penjualanrumah-merosot
Andre Uhde, T. C. (2010). Securitization and systematic risk in european banking: EMpirical Evidence. Journal of Banking and Finance, 3061-3077. doi:http://doi.org/10.1016/j.bankfin.20 10.07.012

Antonio, M. S. (2001). Bank Syariah dari Teori ke Praktek. Jakarta: Gema Insani Press.

Arif, A. (2020). Effect of Securitization and Covered Bonds on Bank Stability. Research in International Business and Finance, 53. doi:https://doi.org/10.1016/j.ribqf.2020 .101196

Ascarya. (2005). Analytic Network Process (ANP) Pendekatan Baru Studi Kualitatif. Jakarta.

Ascarya. (2005). Analytic Network Process (ANP) Pendekatan Baru Studi Kualitatif. Jakarta.

Bedendo, M., \& Linus, S. (2018). The mitigating effect of bank financing on shareholder value and firm policies following rating downgrades. Journal of Corporate Finance, 48, 94-108. doi:https://doi.org/10.1016/j.jcorpfin.2 017.10.019.

Binghui , W. (2018). Asset securitization and rate of return: A study on letters of guarantee. Physica A: Statistical Mechanics and its Applications, 15511554. doi:https://doi.org/10.1016/j. physa.2017.08.143.

Boxall, P. (2013). Mutuality in the Management of Human Resources: Assesing the Quality of Alignment in Employment Relationships. Human Resources Management Journal, 23(1), 3-17.

Claessens, S., \& Horen, N. V. (2012). Being a foreigner among domestic banks: Asset or liability?,. Journal of Banking \& Finance, 36(5), 1276-1290. doi:https://doi.org/10.1016/j.jbankfin.2 011.11.020.

Divisi Pengembangan Produk dan Edukasi . (2016). Standar Produk Perbankan 
Syariah-Murabahah. Jakarta: Otoritas Jasa Keuangan.

Divisi Pengembangan Produk dan Edukasi. (2016). Standar Produk Buku Murabahah. Jakarta: Otoritas Jasa Keuangan.

Edward M. Iacobucci, R. A. (2005, January). Asset Securitization and Asymmetric Information. The Journal of Legal Studies 34, 161-206. doi:https://doi.org/10.1086/4227765

Eugenio Cerutti, J. D. (2017). Housing finance and real-estate booms: A crosscountry perspective, Journal of Housing Economics, 1-13. doi:https://doi.org/10.1016/j.jhe.2017.0 2.001 .

Fekri Ali Sawtari, et.al. (2015). The impact of efficiency on discretionary loans/finance loss provision: A Comparative Studie of Islamic and Conventional Banks. Borsa Istanbul Review, 272-282. Retrieved from http://www.elsevier.com/journals/borsa -istanbul-review/2214-8450

Fianto, B. A., Maulida, H., \& Laila, N. (2019). Determining factors of nonperforming financing in Islamic microfinance institutions. Heliyon, 5(8).

doi:https://doi.org/10.1016/j.heliyon.20 19.e02301

Gary Gorton, A. M. (2012). Securitized banking and the run on repo. Journal of Financial Economics, 104(3), 425-451. doi:https://doi.org/10.1016/j.jfineco.20 11.03.016.

Giddy, I. (2000). New Developments in Asset- Backed Securities. , . Johanessburg. South Africa: Workshop, Host Excellante International.

Gixia, G., \& Ho-Mou, W. (2014). A study on risk retention regulation in asset securitization process. Journal of Banking \& Finance, 45, 61-71. doi:https://doi.org/10.1016/j.jbankfin.2 013.12.027.

Hidayat, R. (2018). Analisis Peluang dan Tantangan Lembaga Keuangan Syariah Untuk Meningkatkan Saya Saing
Menghadapi Masyarakat Ekonomi ASEAN. Amwaluna : Jurnal Ekonmi dan Keuangan Syariah, 2(2), 165-181.

Ilyas, R. (2015, Februari ). Konsep Pembiayaan dalam Perbankan Syari'ah. Jurnal Penelitian, Vol. 9, No. 1.

Imam Wahyudi, G. A. (2014). Interdependence between Islamic capital market and money market:. Borsa_Istanbul Review, 32-47. Retrieved from http://www.elsevier.com/journals/borsa -istanbul-review/2214-8450

John R, B., \& Pedro, J. (2013). Long-term bank balance sheet management: Estimation and simulation of riskfactors. Journal of Banking \& Finance, 37(12), 4711-4720. doi:https://doi.org/10.1016/j.jbankfin.2 013.07.040.

Joshua Yindenaba Abor et.al. (2014). Bank Finance and Export Activities of Small and Medium Enterprises. Review of Development Finance, 97-103.

Kementrian Pekerjaan Umum dan Perumahan Rakyat Repubik Indonesia. (2019, January 4). Kebutuhan Perumahan di Indonesia Masih Tinggi. Retrieved from Pusat Pengelolaan Dana Pembiayaan Perumahan Kementerian Pekerjaan Umum dan Perumahan Rakyat Republik Indonesia: https://ppdpp.id/menteri-puprkebutuhan-perumahan-di-indonesiamasih-tinggi/

Kristina Lützenkirchen, D. R. (2014). Asset portfolio securitizations and cyclicality of regulatory capital. European Journal of Operational Research, 237(1), 289302.

doi:http://www.sciencedirect.com/scie nce/article/pii/S0377221714000137

Kruger, S. (2018). The effect of mortgage securitization on foreclosure and modification. Journal of Financial Economics, $\quad$ 129(3), 586-607. doi:https://doi.org/10.1016/j.jfineco.20 18.01.008.

KSEI. (2015, Agustus). Peraturan KSEI Nomor II-D. Retrieved from Peraturan 
KSEI tentang Pendaftaran Efek Beragun Aset: http://www.ksei.co.id/files/RegulationC SD/Bahasa/Peraturan_KSEI_Tentang_ Pendaftaran EBA.

Loutskina, E. (2011). The Role of Securitization in Bank Liquidity and Funding Management. Journal of Financial Economics, 100(33), 663684.

doi:https://doi.org/10.1016/j.jfineco.20 11.02.005.

Mahfudz, R. B. (2016). Rental index rate as an alternative to interest rate in Musharakah Mutanaqisah home financing: a simulation approach. Emerald Insight.

Mehmet, H. B., Gamze, O. D., Ender, D., \& Amine, T. (2020). Bank credit in uncertain times: Islamic vs. conventional banks. Finance Research Letters.

doi:https://doi.org/10.1016/j.frl.2020.1 01563.

Mingka, A. (2016, January 1). Efek Beragun Asset Syariah. Retrieved from http://www.agustiantocentre.com: http://www.agustiantocentre.com/?p=2 057

Morduch, J. (1999). The role of subsidies in microfinance: evidence from the Grameen Bank. Journal of Development Economics, 229-248. doi:https://doi.org/10.1016/S03043878(99)00042-5

Muhamad. (2016). Manajemen Pembiayaan Bank Syariah . Yogyakarta: UPP STIM YKPN.

Novan, D. S. (2014). Upaya Bank Syariah pada Penyaluran Kepemilikan Rumah Syariah dengan Akad Musyarakah Wal Ijarah Al-Muntahia Bittamlik dalam Hal Terjadi Ingkar Janji.

Novickyte, L., \& Petraityte, I. (2014). Assessment of Banks Asset and Liability Management: Problems and Perspectives (Case of Lithuania). Procedia - Social and Behavioral Sciences, $\quad 110, \quad 1082-1093$. doi:https://doi.org/10.1016/j.sbspro.20 13.12.955.

Rusdyana, A. S. (2015). Aplikasi Metode Analytic Network Process (ANP) dalam Riset Ekonomi \& Keuangan Islam. Bogor: SMART Publishing.

Rusydiana, A. S., \& Devi, A. . (2013). Analytic Network Process: Pengantar Teori dan Aplikasi. Bogor: SMART. Bogor: Smart.

Saaty, T. L. (1993). Pengambilan Keputusan Bagi para Pemimpin. Jakarta: Gramedia. Jakarta: Gramedia.

Satria, M. R., \& Setiani, T. (2018). Analisis Perbandingan Pemberian Kredit Pemilikan Rumah (KPR) Pada Bank Konvensional Dengan Pembiayaan Murabahah (KPR) Pada Bank Syariah (Studi Kasus Pada Bank BJB Dengan Bank BJB Syariah). . Amwaluna: Jurnal Ekonomi dan Keuangan Syariah.

Solomon Y. Deku, A. K. (2019). Securitization, bank behaviour and financial stability: A systematic review of the recent empirical literature. International Review of Financial Analysis, 245-254. doi:https://doi.org/10.1016/j.irfa.2018. 11.013

Taylor D. Nadauld, S. M. (2013). The Impact of Securitization on the Expansion of Subprime Credit. Journal of Financial Economics, 107(2), 454476.

doi:https://doi.org/10.1016/j.jfineco.20 12.09.002.

Thomas, H. (1999). A preliminary look at gains from asset securitization. Journal of International Financial Markets, Institutions and Money, 9(3), 321-333. doi:https://doi.org/10.1016/S10424431(99)00014-1

Tobias, B. (2018). Securitization bubbles: Structured finance with disagreement about default risk. Journal of Financial Economics, 505-518. doi:https://doi.org/10.1016/j.jfineco.20 17.12.001. 
Suci Apriliani Utami, Aneu Cakhyaneu, Neni Sri Wulandari: Analysis of Home Ownership Financing...

Tsung-Kang, C., Hsien-Hsing, L., \& JingSyuan, Y. (2019). Bank management expertise and asset securitization policies. Journal of Banking \& Finance. doi:https://doi.org/10.1016/j.jbankfin.2 019.105667.

Winarto, A. (2017, Oktober 13). Sekuritisasi Sebagai Alternatif Pembiayaan Rumah. 